\section{Retrospective analysis of perioperative mortality after retroperitoneal lymphadenectomy for nonseminomatous testicular tumors}

\author{
Argirović M. Đorđe ${ }^{1}$, Argirović Đ. Aleksandar ${ }^{2}$ \\ ${ }^{1}$ Outpatient Clinic Argirović, Urology, Belgrade, \\ Serbia \\ ${ }^{2}$ Clinical Hospital Center Zemun-Belgrade, Department of \\ Urology, Belgrade, Serbia
}

\section{Abstract}

The present study is performed to determine whether retroperitoneal lymphadenectomy (RPLA) perioperative mortality (PM) rates reported from center of excellence [Indiana University: $0 \%$ for primary and $0.8 \%$ for postchemotherapy (PC) RPLA] are applicable to institution at large. Between 1975 and 2005, 327 assessable patients with nonseminomatous testicular tumors (NSTT) were treated with RPLA: primary in 134 (41\%) and PC-RPLA in 193 (59\%) patients. The observed PM rates were stratified according to age, clinical stage (CS) and type of RPLA. The median age at RPLA was 28 years (range 16-54) : < 29 years in $194(56.3 \%), 30-39$ years in $90(30.3 \%)$ and $>40$ years in $44(13.4 \%)$ patients. Of 327 RPLA patients, 81 (27.8\%) were performed for localized (CS-I), 179 (54.7\%) for regional (CS-II) and 57 (17.5\%) for metastatic (CS-III) disease. Ten (3.1\%) patients died during initial 90 days after RPLA: 1 patient from pulmonary embolism, 2 of chemotherapyrelated toxicity and 7 of progressive disease due to preoperative worse prognostic factors. Of the entire cohort 30, 60 and 90 -day PM rate was $0.3 \%, 1.0 \%$ and $1.3 \%$, respectively. PM rate increase with increasing age: $<39$ years $0 \%, 30-39$ years $5.0 \%$ and $>40$ years 9.3\% ( $\mathrm{x} 2$ trend test, $\mathrm{P}=0.002$ ). PM rate also increased with CS: $0 \%$ localized, $2.8 \%$ for regional and $8.8 \%$ for metastatic disease ( $x 2$ trend test, $\mathrm{p}<0.001)$. PM rate at primary and PC-RPLA was increased with CS: $0 \%$ localized, $2.8 \%$ for regional and $8.8 \%$ for metastatic disease ( $\mathrm{x} 2$ trend test, $\mathrm{p}<0.001$ ). PM rate at primary and PC-RPLA was $0.7 \%$ and $3.1 \% 9 \mathrm{P}<0.001$ ). RPLA was associated with virtually no or low (2.8\%) PM rate in patients with localized and regional disease, respectively. In contrast, the PM rate of $8.8 \%$ for patients with distant metastases and group $>40$ years of age $(9.3 \%)$ implies that RPLA for these patients

\section{Retrospektivna analiza perioperativnog mortaliteta posle retroperitonealne limfadenektomije kod neseminomskih tumora testisa}

Argirovic M. Djordje ${ }^{1}$, Argirovic Dj. Aleksandar ${ }^{2}$

${ }^{1}$ Urološka Klinika, Klinički centar Srbije, Poliklinika Argirović, Urologija, Beograd, Srbija

${ }_{2}$ Kliničko bolnički centar Zemun-Beograd, Urološko odeljenje, Beograd, Srbija

\section{Apstrakt}

Cilj ove studije je da se odredi koliko perioperativni mortalitet (PM) posle retroperitonealne limfadenektomije (RPLA) iznet od strane iskusnih centara (Indiana University: 0\% kod primarne $\mathrm{i}$ $0.8 \%$ kod posthemioterapijske (PH) RPLA) se može primeniti kod institucija u širem smislu. U periodu od 1975. do 2005., 327 pacijenata sa neseminomskim tumorima testisa (NSTT) je lečeno pomoću RPLA: primarna kod 134 (41\%) i PH-RPLA kod 193 (59\%) pacijenata. Učestalost PM je analizirana u zavisnosti od godina starosti, kliničkog stadijuma (KS) i tipa RPLA. Srednje životno doba pri RPLA je bilo 28 godina (raspon 16-54): $<29$ godina kod 194 (56.3\%), 30-39 godina kod 90 (30.9\%) $\mathrm{i}>40$ godina kod $44(13.4 \%)$ pacijenata. Od 327 učinjenih RPLA. 81 (27.8\%) su učinjene kod pacijenata u KS-I, 179 (54.7\%) u KS-II i 57 (17.5\%) u KS-III bolesti. Deset (8.1\%) pacijenata je umrlo tokom inicijalnih 90 dana posle RPLA: 1 pacijent od embolije pluća, 2 od toksiciteta hemioterapije i 7 od progresije bolesti zbog prisustva loših perioperativnih faktora rizika. Učestalost PM na 30, 60 i 90 dana u celoj grupi pacijenata je iznosila $0.3 \%, 1.0 \%$ i $1.3 \%$, respektivno. PM je imao tendenciju rasta sa porastom godina starosti: $<29$ godina $0 \%, 30-39$ godina $5 \% \mathrm{i}>40$ godina $9.3 \%$ (x2 test, $\mathrm{P}=0.002$ ). Učestalost $\mathrm{PM}$ je imala progresiju sa porastom KS: $0 \%$ u KS-I, 2.8\% u KSII i $8.8 \%$ u KS-III bolesti (x2 test, $\mathrm{P}<0.001$ ). PM kod primarne i PH-RPLA je iznosio $0.7 \%$ i $3.1 \%$ $(\mathrm{P}<0.001)$. RPLA je bila udružena sa odsustvom ili niskom (2.8\%) učestalošću PM u KS-I I KS-II. Međutim, učestalost PM od 8.8\% kod pacijenata sa diseminiranim metastazama i grupi pacijenata starosti $>40$ godina $(9.3 \%)$ ukazuju da RPLA za ove pacijente sa visokim rizikom morala biti 
should be performed at centers of excellence, with intent of reducing PM rate.

Key words: testis tumors, nonseminomatous, RPLA, primary, postchemotherapy, perioperative mortality. učinjena u centrima sa velikim iskustvom, sa intencijom da se smanji PM.

Ključne reci: tumori testis, neseminomski, RPLA, primarna, posthemioterapijska, perioperativni mortalitet.

\section{Introduction}

Retroperitoneal lymphadenectomy (RPLA) represent one of the standards of care for patients with all stages nonseminomatous testicular tumors (NSTT) ${ }^{1-8}$. In patients with nonmetastatic germ cell tumors, it is used in first-line therapy, as an alternative to primary chemotherapy or surveillance ${ }^{3-5,9-14}$. It is used either as firstor second-line therapy in patients with regional (retroperitoneal) lymph node metastases ${ }^{3-5}$. Finally, it is used to treat residual disease after chemotherapy in patients with metastatic germ cell tumors ${ }^{3-5}$.

Despite its importance in the management of testicular cancer, only 3 studies have examined perioperative mortality (PM) after RPLA ${ }^{15-17}$. In one of these analyses, wich focused on 478 patients treated with primary RPLA, no deaths was recorded ${ }^{15}$. In contrast, an $0.8 \%$ PM rate was recorded for 603 patients treated with postchemotherapy (PC) RPLA ${ }^{16}$. Among 882 patients managed with RPLA, PM rate was $0 \%$ in patients submitted to primary RPLA and $1.6 \%$ following PC-RPLA ${ }^{17}$. Despite their unquestionable value, these data are applicable to a high select patient population treated with RPLA at centers of excellence (eg, Indiana University Cancer center) because of their exclusive origin from such centers. Thus, these data might not be generalized to RPLA performed at institutions that do not have similar expertise but at which a non-negligible number of RPLAs is performed. Because of these limitations, we decided to perform a population-based study of PM after RPLA in a population -based sample more generalizable to centers with a lesser degree of expertise than that at the Indiana University Center.

\section{Material and Methods Study Population}

We used the data from 327 accessible patients with NSTT treated with RPLA from 1975 and 2006 obtained from our clinical data-base: primary in 134 (41\%) and PC-RPLA in $193(59 \%)$ patients. The observed PM rates were stratified according to age, clinical stage (CS) and type of RPLA. Deaths that occurred within 30, 60 and 90 days of RPLA were considered events. Except for deceased patients, no patient had follow-up of $<90$ days.

\section{Statistical analysis}

The $\mathrm{x} 2$ trend test was used to assess the statistical significance of the difference in proportions. We used the Statistical Package for Social Science life table method to determine the PM rates according to patient age categories $(<19,20-29,30-39,40-49$ and $>50$ years) and SEER stage (localized, regional and metastatic disease).

All statistical tests were performed using Stata, version 6.0 (Stata Corp., College Station, Tx.) and the Statistical Package for Social Science version 12.0 (SPSS, Chicago, Il.).

All tests were 2-sided with significant level set at 0.05 .

\section{Results}

The 327 fully available patients treated with RPLA for NSTT within the study period, had a median age of 28 years (mean 28.8) (range 16-54) : <29 years in $164(56.3 \%), 30-39$ years in $99(30.3 \%)$ and $>40$ years in 44 (13.4\%) patients. Of 327 RPLA patients, 81 (27.8\%) were performed for localized (CS-I), 179 (54.7\%) for regional (CS-II) and 57 (17.5\%) for metastatic (CS-III) disease (Table 1.). 


\begin{tabular}{|c|c|}
\hline VARIABLES & OVERALL COHORT (n=327) \\
\hline Age (yrs) & $28.8($ range 16-54) \\
Mean & 28 \\
Median & $184(56 \%)$ \\
Age category (n) & $99(30 \%)$ \\
$<29 y$ & $44(14 \%)$ \\
$30-39 y$ & \\
$>40 y$ & $91(28 \%)$ \\
SEER stage(n) & $179(55 \%)$ \\
Localized (A/I) & $57(17 \%)$ \\
Regional (B/II) & \\
Metastatic (C/III) &
\end{tabular}

Table 1. Descriptive statistics

Of the entire cohort of 327 patients, one died during initial 30 days (30-day PM rate $0.3 \%$ ). Four additional deaths occurred between 31 and 60 days (60-day PM rate 1.0\%). Five additional patients died between 61 and 90 days after RPLA, for cumulative 90-day PM of 1.3\%. Overall, 10 (3.1\%) died during initial 90 days after RPLA: 1 patient died of pulmonary embolism, 2 of chemotherapy related toxicity and 7 of progressive disease due to perioperative worse prognostic factors. Of the entire cohort 30-, 60- and 90-days PM rates were $0.3 \%, 1.0 \%$ and $1.3 \%$. The cumulative PM rate was $3 \%$. The 30-, 60-, and 90-day PM rate increased with increasing age. At 30- and 60-days, overall PM rate was $1 \%$ and $2 \%$ for age $30-39$ years, $0 \%$ and $4.5 \%$ for age $>40$ years ( $\mathrm{x} 2$ trend test, $\mathrm{P}=0.002$ ). At 90 - days, the $\mathrm{PM}$ rate was $2 \%$ for age $30-39$ years, and $7 \%$ for age $>40$ years ( $\mathrm{x} 2$ trend test, $\mathrm{P}=0.002$ ). Perioperative mortality also increased with increasing stage: $0 \%$ for localized, 5 of $179(2.8 \%)$ for regional and 5 of $57(8.8 \%)$ for metastatic disease ( $\mathrm{x} 2$ trend test, $\mathrm{P}<0.001)$. No deaths occurred in the youngest patient strata $(<29$ years), regardless of disease stage at RPLA. Perioperative mortality rate at primary at PC-RPLA was $0.7 \%$ and $4.7 \%(\mathrm{p}<0.001)$ (Table 2. and 3.).

\begin{tabular}{|c|c|c|}
\hline MORTALITY & $\begin{array}{c}\text { ALL STAGES } \\
\%(95 \% \text { CI; n/Overall) }\end{array}$ & $\begin{array}{c}\text { LOCALIZED DISEASE } \\
\%(95 \% \text { CI; n/Overall) }\end{array}$ \\
\hline$\underline{30 \mathrm{~d}}$ & & \\
\hline Overall & $0.3(0.1-1.2 ; 1 / 327), p=0.04$ & $0.0(0.0-0.8 ; 0 / 91), \mathrm{n} / \mathrm{a}$ \\
\hline Age (y) & & \\
\hline$\leq 29$ & $0.0(0.0-0.8 ; 0 / 184)$ & $0.0(0.0-1.6 ; 0 / 46)$ \\
\hline $30-39$ & $1.0(0.2-2.9 ; 1 / 99)$ & $0.0(0.0-2.3 ; 0 / 31)$ \\
\hline$\geq 40$ & $0.0(0.0-0.1 ; 0 / 44)$ & $0.0(0.0-7.9 ; 0 / 14)$ \\
\hline$\underline{60 \mathrm{~d}}$ & & \\
\hline Overall & $1.2(0.4-3.1 ; 4 / 327), p=0.04$ & $0.0(0.0-0.8 ; 0 / 91), \mathrm{n} / \mathrm{a}$ \\
\hline Age (y) & & \\
\hline$\leq 29$ & $0.0(0.0-0.8 ; 0 / 184)$ & $0.0(0.0-1.6 ; 0 / 46)$ \\
\hline $30-39$ & $2.0(0.4-5.8 ; 2 / 99)$ & $0.0(0.0-2.3 ; 0 / 31)$ \\
\hline$\geq 40$ & $1.0(0.2-2.9 ; 2 / 44)$ & $0.0(0.0-7.9 ; 0 / 14)$ \\
\hline$\underline{90 \mathrm{~d}}$ & & \\
\hline Overall & $1.5(0.3-1.6 ; 5 / 327), \mathrm{p}<0.01$ & $0.0(0.0-0.8 ; 0 / 91), \mathrm{n} / \mathrm{a}$ \\
\hline Age (y) & & \\
\hline$\leq 29$ & $0.0(0.0-0.8 ; 0 / 184)$ & $0.0(0.0-1.6 ; 0 / 46)$ \\
\hline $30-39$ & $2.0(0.4-3.3 ; 2 / 99)$ & $0.0(0.0-2.3 ; 0 / 31)$ \\
\hline$\geq 40$ & $6.8(2.1-7.7 ; 3 / 44)$ & $0.0(0.0-7.9 ; 0 / 14)$ \\
\hline
\end{tabular}

Table 2. Mortality rates at 30,60 and 90 days after RPLA 


\begin{tabular}{|c|c|c|}
\hline MORTALITY & $\begin{array}{l}\text { REGIONAL DISEASE } \\
\% \text { (95\%CI; n/Overall) }\end{array}$ & $\begin{array}{c}\text { METASTATIC DISEASE } \\
\%(95 \% \text { CI; n/Overall) }\end{array}$ \\
\hline $\begin{array}{c}\underline{30 \mathrm{~d}} \\
\text { Overall } \\
\text { Age }(\mathrm{y}) \\
\leq 29 \\
30-39 \\
\geq 40 \\
\underline{60 \mathrm{~d}} \\
\text { Overall } \\
\text { Age }(\mathrm{y}) \\
\leq 29 \\
30-39 \\
\geq 40 \\
\underline{90 \mathrm{~d}} \\
\text { Overall } \\
\text { Age }(\mathrm{y}) \\
\leq 29 \\
30-39 \\
\geq 40\end{array}$ & $\begin{array}{c}0.3(0.0-1.5 ; 1 / 179), \mathrm{p}=0.6 \\
0.0(0.0-1.8 ; 0 / 101) \\
0.8(0.0-4.6 ; 1 / 55) \\
0.0(0.0-6.6 ; 0 / 23) \\
\\
1.1(0.0-4.5 ; 2 / 179), \mathrm{p}=0.6 \\
0.0(0.0-1.8 ; 0 / 101) \\
3.6(0.0-6.9 ; 2 / 55) \\
0.0(0.0-6.6 ; 0 / 23) \\
\\
1.1(0.0-4.5 ; 2 / 179), \mathrm{p}=0.8 \\
\\
0.0(0.0-1.8 ; 0 / 101) \\
0.0(0.0-9.9 ; 0 / 55) \\
8.7(8.1-24.2 ; 2 / 23)\end{array}$ & $\begin{array}{c}0.0(0.0-6.0 ; 0 / 57), \mathrm{p}=0.2 \\
0.0(0.0-5.1 ; 0 / 27) \\
0.0(0.0-1.1 ; 0 / 13) \\
0.0(0.0-1.3 ; 0 / 17) \\
3.5(0.9-12.5 ; 2 / 57), \mathrm{p}=0.3 \\
\\
0.0(0.0-5.1 ; 0 / 27) \\
8.3(2.5-30.2 ; 0 / 13) \\
5.9(0.0-11.9 ; 1 / 17) \\
5.3(1.7-14.6 ; 3 / 57), \mathrm{p}=0.05 \\
\\
0.0(0.0-11.9 ; 0 / 27) \\
11.5(2.5-30.2 ; 1 / 13) \\
16.7(2.1-48.4 ; 2 / 17)\end{array}$ \\
\hline
\end{tabular}

Table 3. Mortality rates at 30, 60 and 90 days after RPLA

Data stratification according to disease stage at RPLA revealed that at 30-, 60--, and 90- days, no deaths occurred in patients with pathologically confirmed localized NSTT. In patients with regional disease, $5(3.8 \%)$ deaths of 179 patients occurred (95\% CI, 1.2\%-10.5\%). Finally, in patients with metastatic disease, 5 of 57 patients died, for a $8.8 \%$ 90-day PM rate (95\% CI, 2.1\%-14.6\%).

Our findings can be summarized in the following fashion. RPLA carries virtually no risk of PM in patients with localized disease, regardless of stage. However, patients with regional and metastatic disease should be informed about moderate (2.8\%) and significantly greater (8.8\%) PM rate, respectively. When no pathologically confirmed lymph node metastases were recorded at RPLA, No PM deaths occurred. Similarly, no deaths were recorded when the RPLAs were performed in younger men $(<30$ years), regardless of stage of disease. However, a low, yet detectable, PM rate was recorded for patients with regional (retroperitoneal) lymph node metastases whose age was $>30$ years. In those patients at 30-, 60-, and 90-days the PM rate was $0.6 \%, 0.6 \%$ and $1.7 \%$, respectively. Significantly greater PM rates were recorded in patients with metastatic NSTT treated with RPLA. In those patients, at 30-, 60- and 90-days, the PM rate was $4.5 \%, 4.5 \%$ and $6.0 \%$, respectively (Figure 1.).

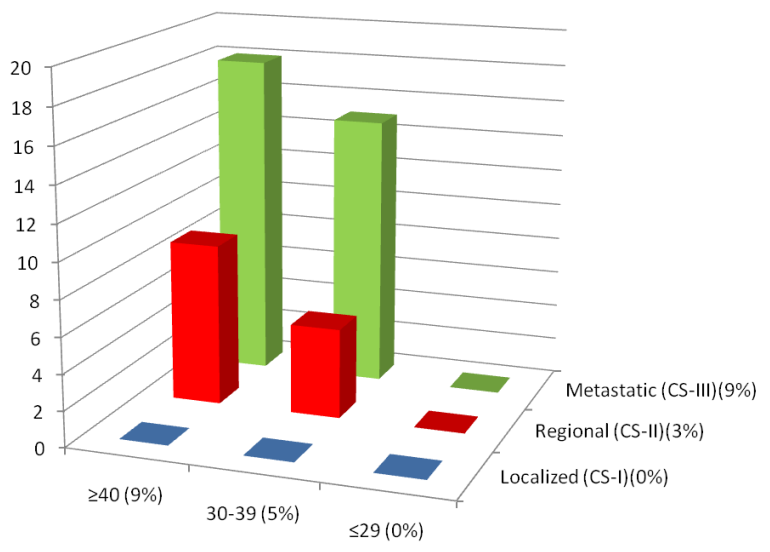

Localized (CS-I)(0\%)

- Regional (CS-II)(3\%)

Metastatic (CS-III)(9\%)

Figure 1.90-day mortality rates after RPLA for 327 pts stratified according to age and stage 


\section{Discussion}

RPLA represents a therapeutic and/or staging modality for patients with virtually all stage NSTT. RPLA, performed by expert surgeons, is believed to represent a safe surgical intervention with minimal morbidity and virtually no mortality ${ }^{18,19}$. Despite its central role in the management of testicular cancer, only 2 studies from the same institution have addressed PM after RPLA ${ }^{15,16}$. In these reports, 478 patients treated with primary RPLA ${ }^{15}$ and 603 patients treated with PC-RPLA ${ }^{16}$ were studied. No mortality was recorded in the setting of primary RPLA ${ }^{15}$. However, a $0.8 \%$ mortality rate at $<47$ days after surgery was reported for patients who had undergone PC-RPLA ${ }^{16}$.

These studies have demonstrated that patients treated at a tertiary care referral center can expect outstandingly safe surgical outcomes. However, many RPLAs will be performed at institutions with substantially less expertise than that at Indiana University or Memorial Sloan-Kettering Cancer center, examples of RPLA centers of excellence. At centers with lesser clinical and surgical expertise, patient selection and perioperative patient care might differ from those at centers of excellence. This could have a significant effect on postoperative complications and, possibly, on PM. Thus, Pm data from a center of excellence, such as Indiana University, are applicable to another center of excellence but not to institutions at which RPLSAs are performed in much lower numbers. Therefore, we examined the PM rate after RPLA for NSTT using data from the SEER data base, which does not include Indiana University or the memorial Sloan-Kettering Cancer Center. Our objective was to deter mine the population-based RPLA PM rates providing from our center.

The SEER data demonstrated that, in general, PM rate is low for patients treated with RPLA for NSTT ${ }^{15}$, $16,20,21$.

Several points deserves mention. First, our PM data regarding localized disease were comparable to those from Indiana University. Thus, patients with localized disease treated with RPLA have virtually no risk of PM at tertiary care centers, as well as at other centers with lesser degrees of expertise.

Second, data from Capitanio and colleagues ${ }^{17}$ on PM rate in patients with regional-stage NSTT treated with RPLA were also comparable to those reported from Indiana University ( $0.8 \%$ vs. $0.8 \%)$. However, PM rate in CS-II disease reported in our study is substantially higher in comparison to previously reported results (4.7\% vs. $2.6 \%$ vs. $0.8 \%$ ). Thus, in patients treated with RPLA for regional disease PM outcomes equally favorable to those from centers of excellence can also be expected.

Third, the present report is the second published till now on PM rate exclusively in men with metastatic NSTT. Our finding indicate that RPLA in this setting is associated with a non-negligible PM rate (8.8\%) across all age categories, similar to those reported by Capitanio and colleagues (7\%) ${ }^{17}$. This finding needs to be addressed during the informed consent process with the patient. Moreover, RPLA should be performed at centers of excellence, with the intent of reducing the PM rate.

Although we only focused on PM, several other indicators of quality of care also deserve attention; for example, the completeness of the RPLA. The recurrence and cause-specific mortality rates represent others. Our study was not designed to address these end points. Nonetheless, our results should be interpreted in light of those considerations. Additionally, we could not assess the effect of comorbid conditions at baseline. Some comorbidities, for example pulmonary toxicity, might predispose patients to a greater risk of PM. Information about the specific non-cancer causes of death could help in identifying the most frequent risk factors for PM after RPLA, such as bleeding, pulmonary embolism, or myocardial infarction. Finally, our database contains the length of stay or discharge information. These data could allow more detailed analyses, which could potentially be completed with other databases. Despite these limitations, our results have provided valuable information that warrants additional corroboration.

\section{Conclusions}

Our results have shown that RPLA is associated with virtually no PM in patients with localized disease. Our finding virtually perfectly replicated the PM rate reported at Indiana University with CS-I. An intermediate 
PM rate $(2.8 \%)$ can be expected in men with regional disease. Finally, elevated PM (8.8\%) might be expected in men with metastatic NSTT.

\section{Acknowledgment}

We cordially thank to Natalija Šeparević from Hypo Alpe Adria, Hypo facilities services, Belgrade for the help in statistical analysis and to Iva Popović from City Image, Belgrade for the technical assistance in the preparation and edition of this manuscript.

\section{Literature}

1. Heidenreich A, Ohlmann C, Hegele A, et al. Repeat retroperitoneal lymphadenectomy in advanced testicular cancer. Eur Urol 2005; 47: 54-71.

2. Argirovic D, Argirovic A. Management of clinical stage A, B1 and B2 with nonseminomatous testicular tumors upfront retroperitoneal lymphadenectomy. Eur Urol Suppl 2009; 8: 624.

3. Motzer RJ, Bolger GB, Boston B, et al. Testicular cancer: clinical practice guidelines in oncology. J Natl Compr Cancer New 2006; 4: 1038-58.

4. Albers P, Albrecht W, Algaba F, et al. Guidelines on testicular cancer. Eur Urol 2005; 48: 885-94.

5. van As NJ, Golbert DC, Money-Kyrle J, et al. Evidence-based pragmatic guidelines for the follow-up of testicular cancer: optimizing the detection of relapse. J Urol 2007; 178: 500-03.

6. Lowrance WT, Cookson MS, Clark PE, et al. Assessing retroperitoneal lymph node dissection: does it still have a role in the management of clinical stage I nonseminomatous testis cancer? A European perspective. Eur Urol 2008; 54: $1008-15$.

7. Heidenreich A, Thuer D, Polyakov S. Post-chemotherapy retroperitoneal lymph node dissection in advanced germ cell tumours of the testis. Eur Urol 2008; 53: 260-72.

8. Rassweiler J, Scheirtlin W, Heidenreich A, et al. Laparascopic retroperitoneal lymph node dissection: does it still have a role in the management of clinical stage I nonseminomatous testis cancer: A European perspective. Eur Urol 2008; 53: 260-72.

9. Argirovic D, Argirovic A. High risk clinical stage A nonseminomatous testicular tumors: Primary retroperitoneal lymphadenectomy or cisplatin-based chemotherapy? Eur Urol Suppl 2009; 8: 507.

10. Argirovic D, Jelic-Radosevic Lj, Argirovic A. Primary chemotherapy in low clinical stage germ cell testicular tumors: a feasible mode of treatment. Eur Urol Suppl 2010; 9(6): 539.

11. Chevreau C, Mozerolles C, Soulie M, et al. Long-term efficacy of two cycles of BEP regimen in high- risk stage I nonseminomatous testicular germ cell tumors with embryonal carcinoma and/or vascular invasion. Eur Urol 2044; 46: $209-14$.

12. Argirovic $\mathrm{Dj}$, Argirovic A. High risk clinical stage A nonseminomatous testicular tumors: patterns of recurrence and outcome of treatment. Urology 2007; 70 (Suppl 3A): 164.

13. Argirovic D. Primary retroperitoneal lymphadenectomy or cisplatin-based chenmotherapy in clinical stage B1/B2 neseminomatous testicular tumors: Long- term results of the prospective non-randomized study. Eur Urol Meet 2007; 2(7): 137.

14. Weissbach L, Bussar Maatz R, Flechtner H., et al. RPLND or primary chemotherapy in clinical stage IIA/B nonseminomatous germ cell tumors. Results of a prospective multicenter trial including quality of life assessment. Eur Urol 2000; 37: 582-94. 
15. Baniel J, Foster RS, Rowland RG, et al. Complications of primary retroperitoneal lymph node dissection. J Urol 1994; 152: 582-94.

16. Baniel J, Foster RS, Rowland RG, et al. Complications of post-chemotherapy retroperitoneal lymph node dissection. J Urol 1995; 153: 976-80.

17. Capitanio U, Jeldres C, Perrotte P, et al. Population-based study of perioperative mortality after retroperitoneal lymphadenectomy for nonseminomatous germ cell tumors. Urology 2009; 74(2): 373-7.

18. Sheinfeld J. Risks of uncontrolled retroperitoneum. Ann Surg Oncol 2003; 10: 100-01.

19. Sheinfeld J, Sogani P. Reoperative retroperitoneal surgery. Urol Clin North Amer 2007; 34: 227-30.

20. Baniel J, Sella A. Complications of retroperitoneal lymph node dissection in testicular cancer: primary and postchemotherapy. Semin Surg Oncol 1999; 17: 263-67.

21. Baniel J, Foster RS, Rowland RG, et al. Complications of primary retroperitoneal lymph node dissection for lowstage testicular cancer. World J Urol 1994; 12: 139-42.

22. Argirović Đ, Argirović A. Analiza rezultata posthemioterapijske retroperitonealne limfadenektomije kod pacijenata sa intramedijarnim i lošim rizikom neseminomskih tumora testisa. Materia Medica 2011;27:352-60.

23. Argirović Đ, Argirović A. Patološki nalaz i klinički tok kod pacijenata sa metastazama neseminomskih testikularnih tumora kod kojih je primenjena retroperitonealna limfadenektomija posle multiplih hemoterapija. Materia Medica 2011;27:195-202.

Corresponding author:

Đorđe Argirović

Outpatient Clinic Argirović, Urology

11.120 Belgrade

Serbia

Tel.: ++381 112788 498, 2788900

Fax.: ++ 381113290324

Mob.: ++ 38163236659

E-mail: cvijiceva@yubc.net 